\title{
ANALISIS SEGMENTING TARGETING DAN POSITIONING UNTUK MERUMUSKAN STRATEGI PEMASARAN REGIONAL PADA UMKM CHRISTINE HAKIM DI PADANG
}

\author{
Marta Widian Sari \\ Universitas Putra Indonesia YPTK Padang,Indonesia \\ Email : $\underline{\text { martawidiansari@ upiyptk.ac.id }}$
}

\begin{abstract}
This study aimed to find out and analyze the analysis of the Segmenting, Targeting, and Positioning to formulate the Regional marketing strategy on UKM Christine Hakim a study On UKM Christine Hakim on JL. Nipah, no. 38, Padang Barat, Padang of West Sumatra. This research aims to find out how market opportunity, market segmentation, target market, product Positioning and strategy of marketing mix 4 p's product, price, promotion and distribution of products in formulating an Asean Regional marketing strategy On UKM in the Christine Hakim. With the collection of data using interviews and primary data. Research results are obtained, (1) UKM product Markets opportunities Christine Hakim in Asean Regional Market potential fairly, (2) market segmentation based on Demographic segmentation, (3) the Target market the overall income level, (4) positioning products "if not stop by the UKM Charistine Judge means has not been to Padang", (5) product strategy of adaptation and expansion of the communication, (6) pricing strategy Penertation Princing, (7) promotion strategy the strategy of expanding Communication (8) the distribution strategy through intermediaries and Partners in Asean countries and cooperation by establishing an Export Organization. Finally the author suggests UKM Christine Hakim in the Asean Regional market entry, and to enter the Asean Regional markets by implementing a marketing strategy (STP) strategies and marketing mix.
\end{abstract}

Keywords: Segmenting, Targeting, Positioning, and Regional marketing strategies

\section{Pendahuluan}

Pada saat ini, persaingan di dunia usaha semakin ketat dan kompleks. Banyak perusahaan berkonsentrasi untuk mendapatkan posisi terbaik dipasar daripada hanya sekadar bertahan hidup. Oleh karena itu, perusahaan tidak hanya berusaha mendapatkan konsumen yang baru tetapi juga berusaha keras untuk mempertahankan pelanggan yang telah mereka dapatkan. Di lihat dari volume penjualan kripik balado sebagai corak makan khas Sumatra Barat dan Bukittinggi ini menngalami peningkatan setiap tahunnya sejak berdiri UMKM Christine Hakim.

Tabel 1.1

LAPORAN PENJUALAN

KERIPIK BALADO CHRISTINE HAKIM PADANG TAHUN (2013-2016)

\begin{tabular}{|c|c|c|}
\hline TAHUN & VOLUME PENJUALAN & \% PENJUALAN \\
\hline 2013 & 2250 Bungkus & - \\
\hline 2014 & 2587 Bungkus & $20 \%$ \\
\hline 2015 & 2745 Bungkus & $22 \%$ \\
\hline 2016 & 2925 Bungkus & $30 \%$ \\
\hline TOTAL & $\mathbf{1 0 5 0 7}$ bungkus & $\mathbf{7 2 \%}$ \\
\hline
\end{tabular}

Sumber : Data primer Christine Hakim (Oktober 2016) 
Dari perbandingan penjualan keripik balado Christine Hakim pada tahun 2013 dan 2016 terus mengalami peningkatan dalam penjulan. Dimana pada tahun 2013-2014 penjualan keripik balado Christin Hakim mengalami kenaikan sebesar 20\% dari penjualan kripik balado. Hal ini karena manajemen yang sudah mulai tertata dengan rapi dan mulai merambah ke dunia emarketing. Pada tahun 2015 terjadi kenaikan 22\% yang tidak terlalu signfikan dari tahun sebelumnya karena pengaruh infalasi sehingga menimbulkan penurunan daya beli masyarakat. Pada tahun 2016 sampai oktober terjadi kenaikan 30\% dari tahun sebelumnya disebabkan karena program kerja pemerintah dari Sumatera Barat mengenjot laju wisata di Kota Padang sebagai kota wisata sehingga mempunyai pengaruh yang cukup besar terhadap daya beli masyarakat maupun wisatawan yang atang ke Sumatera Barat. Dari hasil pengamatan, fenomena yang terjadi sekarang adalah masih banyak mahasiswa fakultas ekonomi jurusan manajemen melihat kelompok acuannya seperti teman, mahasiswa fakultas ekonomi jurusan manajemen menggunakan bedak padat pesaing dengan alasan sudah cocok diwajah dna harga yang murah. Maka dari itu keanekaragaman konsumen dalam membeli suatu produk dipengaruhi oleh faktor - faktor pengambilan keputusan.

\section{Tinjauan Pustaka Pengertian Segmenting}

Menurut Menurut Kotler (2012) Segmentasi pasar yang terdiri dari sekelompok pelanggan yang memiliki sekumpulan kebutuhan dan keinginan yang serupa. Berdasarkan definisi diatas bahwa segmentasi pasar merupakan suatu aktivitas membagi atau mengelompokkan pasar yang heterogen menjadi pasar yang homogen atau memiliki kesamaan dalam hal minat, daya beli, geografi, perilaku pembelian maupun gaya hidup.

\section{Pengertian Targeting}

Adalah proses mengevaluasi segmentasi dan memfokuskan strategi pemasaran pada suatu negara ,provinsi, atau sekelompok orng memiliki potensi untuk memberikan respon, Keegan dan Green (2008).

\section{Pengertian Positioning}

Menurut Lamb, Hair, McDaniel (2003: 205)Positioning adalah merubah persepsi konsumen relasi brand menjadi kompetisi brand.posisi (positioning) dipopulerkan pertama kali oleh Al Ries dan Jack Trout pada tahun 1972. strategi positioning merupakan strategi yang berusaha mencipatakan diferensiasi yang unik dalam benak pelanggan sasaran, sehingga terbentuk citra (image) merek atau produk yang lebih unggul dibandingkan merek/produk pesaing.

\section{Pemasaran Regional}

Menurut Warren j. Keegan (2007:151) mendefenisikan pasar Regional merupakan usaha yang mengelompokkan negara dimana persamaan dalam kelompok dan perbedaan antar kelompok akan tampak semaksimal mungkin. 


\section{Kerangka Fikir}

\section{Kerangka Pikir}

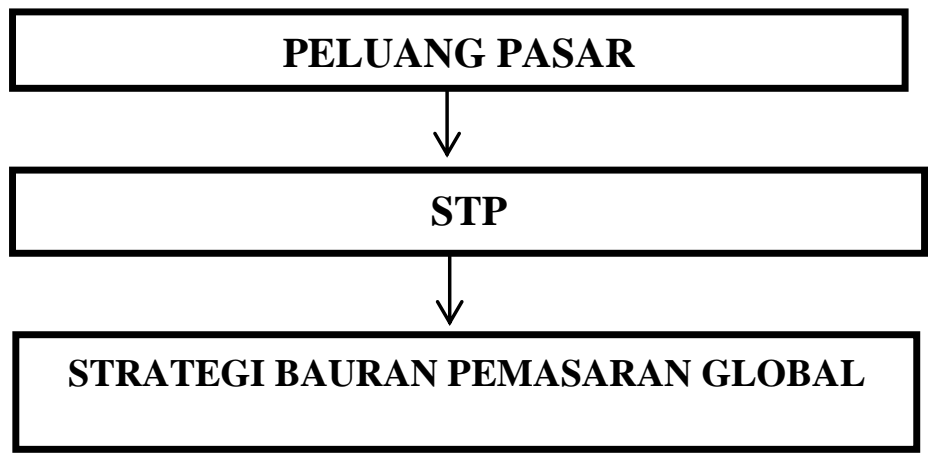

\section{Hipotesis}

H1: Adanya peluang pasar produk UKM Christine Hakim dinegara Asean

H2: Adanya Segmentasi pasar produk UKM Christine Hakim dinegara Asean didasarkan pada analisis peluang pasar $(4 \mathrm{p})$

H3: Dari segmentasi di negara Asean target pasar produk UKM Christine Hakim adalah Negara malaysia, Singapura, dan Brunai Darussalam.

H4: Positioning Produk UKM Christine Hakim di pasar Asean dengan Menonjolkan ciri Khas dan budaya asal produk tersebut.

H5: Dengan strategi Bauran Pemasaran (4P) Produk, Harga, Distribusi dan Promosi untuk produk UKM Christine Hakim maka peluang pasar Regional dapat dimasukkan.

\section{Metodologi Penelitian}

\section{Objek Penelitian}

Dalam melakukan penelitian ini objek yang diteliti yaitu, UMKM Christine Hakim yang terletak di Jln.Berok Nipah No 38 padang Barat, kota Padang Sumatera Barat.

\section{Desain Penelitian}

Penelitian yang penulis lakukan termasuk kedalam jenis penelitian deskriptif, penelitian deskriptif dilakukan untuk menjelaskan berbagai variabel penelitian dalam situasi tertentu. Penelitian ini dapat pula disebut sebagai penelitian yang menjelaskan fenomena apa adanya. Dalam hal ini variabel bebas adalah Segmenting,Targetig dan Positioning terhadap Strategi Pemasaran Regional pada UMKM Christine Hakin di di Jln.Berok Nipah,padang Barat, kota Padang Sumatera Barat.

\subsection{Populasi dan sampel Teknik Pengumpulan Data}

Dalam penelitian ini teknik yang dilakukan untuk mengumpulkan data, yaitu:

\section{Data Primer}

Untuk mengumpulkan data primer yaitu dengan melakukan survey pada UKM Christine Hakim di Jln. Nipah No 38 Kota Padang Sumatera Barat.

\section{Data Skunder}


Dengan mengumpulkan data melalui studi literatur dan dengan laporan dari instansi terkait.

\section{Metode Analisis Data}

Mendeskripsikan Segmentasi, Targeting dan Positioningdan Strategi bauran Pemasaran 4P

\section{Hasil dan Pembahasan}

\section{Hasil Analisis SWOT}

Beberapa faktor eksternal yang dipertimbangkan, baik itu peluang maupun ancaman, total nilai yang dihasilkan akan berkisar dari 1,0 untuk yang sangat rendah dan sampai 4,0 untuk yang sangat tertinggi, dan sekitar rata-rata 2,8 yang dipersamakan dengan 3.0 dengan demikian perusahaan dengan keadaan yang ada mampu memamfaatkan peluang secara optimal serta mampu meminimalisir ancaman yang hanya sebesar 1.5 dengan menggunakan kekuatan internal perusahaan, dengan kata lain posisi UKM Christine Hakim dipadang mampu dalam menghadapi dinamika lingkungan eksternal.

Jadi dari ke empat kuadran tersebut, kuadran yang paling menguntungkan bagi UKM Christine Hakim dipadang adalah Kuadran I yaitu, memamfaatkan kekuatan untuk mendapatkan peluang. Maka pilihan strategi iyalah strategi pertumbuhan.

\section{Strategi masuk Pasar Regional Asean Joint Venture}

Melalui strategi Joint Venture UKM Christine Hakim melakukan perjanjian Kemitraan (partnership) di Malaysia, Singapure, dan Brunai Darussalam untuk mendirikan usaha lokal, yang keduanya berbagi kepemilikan dan pengendalian. Keuntungan dari strategi ini adalah adanya pembagian dalam menangung resiko dan kemampuannya mengkombinasikan dua kekuatan untuk menciptakan sinergi

\section{Strategi masuk Pasar Regional Asean Ekspor}

Cara ekspor adalah cara paling sederhana dalam memasuki pasar di negara lain, aktifitas ekspor merupakan kegiatan produksi barang dari suatu negara dengan menjual hasilnya ke negara lain.

\section{Kesimpulan}

Berdasarkan hasil penelitian dan pengujian hipotesis yang telah dilakukan, maka hasil penelitian dapat disimpulkan sebagai berikut :

1. Peluang pasar untuk memasuki Pasar Regional bagi UKM Asean cukup potensial.

2. Segmentasi pasar Regional Asean Produk UKM Christine Hakim didasarkan pada Demografi Segmentasi.

3. Target pasar produk UKM Christine Hakim di Pasar Regional Asean berdasarkan keseluruhan tingkat pendapatan, karena produk UKM Christine Hakim Harga yang bervariasi yang terjangkau untuk semua kalangan.

4. Memposisikan produk UKM Christine Hakim dipasar adalah "Kalau belum mampir ke UKM Charistine Hakim berarti belum Ke Padang".

5. Strategi Bauran pemasaran 4P UKM Christine Hakim di Pasar Regional Asean.
a) Strategi Produk
Strategi Produk UKM Christine Hakim di Pasar Asean menggunakan Strategi
Startegi Adaptasi dan perluasan Komunikasi.
b) Strategi Harga 
Strategi Harga UKM Christine Hakim di Pasar Asean menggunakan Strategi (Penertation Princing)

c) Strategi Promosi

Strategi Promosi UKM Christine Hakim di Pasar Regional Asean menggunakan strategi Perluasan Komunikasi memperluas, tanpa mengubah, strategi komunikasi sama dengan Pasar di Negara sendiri, hanya saja produk yang diadaptasikan sesuai dengan permintaan pasar.

d) Strategi Distribusi

Strategi Distribusi UKM Christine Hakim di Pasar Asean menggunakan Perantara Patner dinegara Asean dan kerjasama dengan membentuk sebuah Organisasi Ekspor.

\section{Saran}

- Berdasarkan kesimpulan diatas penulis menyarankan UKM Christine Hakim di Padang untuk memasuki Pasar Regional Asean.

- Untuk memasuki pasar Regional Asean tersebut dengan mengimplementasikan strategi pemasaran (STP) dan strategi bauran pemasaran.

\section{References}

[1] Akinyele,2010, "Strategic Marketing Management of Oil and Gas Industry: A Revie of Literature", Journal of Business Management and Economics, Vol. 1, no. 1, pp. 001-009.

[2] Kotler.Philip and Gary Armstrong. 2012. Prinsip-prinsip Pemasaran. Edisi13. Jilid 1. Jakarta: Erlangga.

[3] Charles W. Lamb, Joseph F. Hair, Carl Mcdaniel. 2001. Pemasaran. Edisi Pertama,Salemba Empat, Jakarta.

[4] Abdullah, Thamrin dan Francis Tantri.2012. Manajemen Pemasaran. Jakarta: PT Raja Grafindo Persada

[5] Basu,Swastha,dan Irawan, 2006, Manajemen Pemasaran Modern, Liberty,Yogyakarta

[6] Jiptono, Fandy, 2008, Strategi Pemasaran, Edisi 3, ANDI: Yogyakarta.

[7] Drs. A. Hasymi Ali, Manajemen Distribusi Fisik dan Manajemen Material . Jakarta: Penerbit Bumi Aksara.

[8] Kasali, Rhenaldi, 2001, Membidik Pasar Indonesia:Segmentation, Targeting and Positioning, Jakarta; Gramedia Pustaka Utama.

[9] Lamb, Charles W, Hair, Joseph F, dan McDaniel. 2001. Pemasaran, Buku1. Salemba Empat, Jakarta.

[10] Kotler, Philip \& Kevin Lane Keller, 2006, Marketing Management, International Edition, New York; Pearson.

[11] Keegan, Warren J., Mark C. Green. (2008). Global Marketing.(5thed.) Pearson Prentice Hall, London

[12] Aaker, David A. 2013. Manajemen Pemasaran Strategi. Edisi kedelapan. Salemba Empat. Jakarta.

[13] Keegan, Warren J, (2007). Manajemen Pemasaran Global. Edisi Keenam Jilid 1. Jakarta: PT INDEKS Kelompok Gramedia.

[14] Kotler,Philip and Gary Armstrong. 2012. Prinsip-prinsip Pemasaran. Edisi13. Jilid 1. Jakarta: Erlangga.

[15] Frenddy,Rangkuty, 2008, Analisis SWOT. Penerbit Andi : Yogyakarta. 
[16] Badan Pusat Statistik. Jumlah penduduk kota padang 2015. Provinsi Sumatera Barat : BPS, 2015

[17] Maharani rahman,” Industri keripik balado Christine Hakim 1990-2007 : Studi Tentang sejarah berdirinya industri keripik balado Christine Hakim Skripsi. Padang : Fakultas Sastra Universitas Andalas.

[18] http://finance.detik.com/berita-ekonomi-bisnis/d-3119267/ri-paling-rajin-ekspor-ke-10negara-ini

\section{Jurnal}

Prima Adi Surya Pristiwati, Panji Deoranto, Rizky L. R. Silalahi

(Pengaruh Strategi Segmenting, Targeting, Dan Positioning Terhadap Keputusan Pembelian Konsumen (Studi Kasus Di Rumah Makan Ayam Bakar Wong Solo)

Siska Dwi Widyawati, Syarif Imam Hidayat, Endang Yektiningsih. ( ANALISIS SEGMENTASI, TARGETING DAN POSITIONING (STP) DALAM PENJUALAN PRODUK KECAP CAP KOKI DOLLAR DI TULUNGAGUNG)

Denada R, Kevin (2016) (Analisis Positioning Produk olahraga Merek Specs, Nike, Adidas dan Leguage DI pemain futsal Universitas Negerri Yogyakarta).

Oleh Sylvia Tri Astina,Sunarti, M. Kholid Mawardi (Analisis Segmenttation, Targeting, dan Positioning dalam rangka meningkatkan daya saing melauli strategi pemasaran di took Pia Cap Mangkok Semeru).

www.wardahbeauty.com

www.topbrand-award.com 